\title{
Christina Hesselholdt
}

\section{Fire stykker prosa}

Vi var i færd med at klatre op ad en klint, der er omkring hundredehalvtreds meter høj, da det begyndte-at blive mørkt (mit ur var gået i stå, og vi var taget af sted meget senere, end vi troede). Vi var omtrent halvtreds meter fra toppen, da det blev helt mørkt, og vi kunne ikke fire os ned, vandet var steget, og der var ikke længere strand under os, men hav.

Vi klatrede de sidste halvtreds meter i mørke - men lyset fra et fyrtårn oplyste klinten omtrent hvert syttende sekund. Når lyset faldt på klippen, ledte vi efter det næste hul at anbringe hænder eller fødder i og trak os længere op, blændede af lyset, der skyllede hen over os. Det blev igen mørkt, og i løbet af de næste par sekunder vænnede øjnene sig til mørket. Så kom lyset tilbage. Sådan blev det ved, indtil vi ved midnat omsider nåede helt op. 
Gående inden for den samme flimrende beklædning, mørket, kunne vi ikke se hinandens kroppe (jeg formoder da, at de heller ikke kunne se min).

Den enes ansigt var langt, og den andens var rundt. Jeg ved ikke, hvad de hed, men de var mørke, og jeg er lys. Vi gik med hinanden $\mathrm{i}$ hånden.

Der var rødder, der fik os til at snuble, og grene, der stak, og et pludselig elevatorisk sug, idet jorden blev væk under os - lidt efter gjorde vi os fri af hinandens klaskende lemmer og rejste os i en grøft.

Så fandt vi alligevel trappen, der førte ad skråningen ned mod søbredden, og vi gik ned ad de høje og uregelmæssige trin. Trappen var så kridhvid og stejl og gammel. Der kom lyde fra festen, et sted langt bag os. Der lugtede stærkt af sø, og det rev i mig efter at komme frem.

Trappens trin forsvandt i søen, og vi blev ved at gå, til der ikke var flere trin, men en bund af den type, der giver efter, blød af alt det, som ligger og rådner. Så slap vi hinandens hænder og lod os hver især glide fremefter. Vandet var lunt. Det lange ansigt og det runde ansigt nikkede over den fælles krave af sort vand.

„Der er sytten meter vand under os nu", sagde ham med det runde ansigt.

Sytten meter sort, men roligt vand. 
Det her er syden: Himlen er et kolossalt øje, som mørket lukker sidst på eftermiddagen.

Hvorfor anbringe sig et sted, der næsten er en grav? Længst fra himlen, naturligvis. Naturligvis? Ja. "Nu kan du vist ikke komme længere væk fra himlen", sagde jeg til mig selv. Jeg kunne selvfølgelig have ventet til det blev mørkt. Men jeg kunne ikke vente.

Så råbte jeg til solen, at den skulle farve, så det ikke blev til at afgøre, hvor kødet begynder, og jorden holder op. Og til min kjole sagde jeg: „Brænd, gør". Og til den tunge, som ikke var der: "Slik min strube". Og det var alt sammen værgeløst: Strube, kjole, jorden, der skred under min røv. Munden væltede, og hvorfor var der ikke andre tænder end mine, i en anden væltende mund.

Der var altså kjolen: Partner. Bagefter blev jeg siddende længe, og solen begyndte at gå ned. Min arm sov, men jeg bevægede den ikke. Til sidst føltes det, som om det ville blive umuligt nogensinde igen at bruge den. Den blev noget tungt, der ikke rigtig tilhørte mig, men som udøvede et nedadgående træk. Kunne min sovende arm trække mig i jorden? 
Grevinden kender mig ikke.

På den anden side af søen rejser jeg et skævt tårn af strå, der vildt rækker ud mod slotstårnets lodrette murværk, hvor hun står med sin buede mund bag de runde vægge, og tårnets ruder presser hun en efter en den mund imod.

Efter syv dage står det der; tættere kommer jeg ikke grevinden, og jeg kan sige til vinden: „Flå“, og „Værs' go" til regnen.

Først skal jeg forsvinde, så skrider måske mit tårn, jordslået, opløst i søen; næsten det intet jeg kom fra og går til.

I natten efter den syvende dag står jeg, uset, en ingen, blandt nedstyrtede bikuber og stirrer mod slottet, hvor grevinden drevet af min tanke (om ikke at være til som enhver) må vandre fra værelse til værelse for bag hver eneste rude at tænde et lys.

En time før daggry den ottende dag er også hun færdig og allerede forsvundet mod syd i sit mørkerøde automobil.

En umådelig mængde lys blafrer. Dem må grevindens mand slukke; det gør jeg så.

Note: den sidste tekst er skrevet sammen med Claus Beck-Nielsen 